\title{
HIV, Antiretroviral Therapy and Metabolic Alterations: A Review
}

Huseyin Ekin Ergin ${ }^{1}$, Evelyn E. Inga ${ }^{2,3}$, Tun Zan Maung ${ }^{2}$, Mehwish Javed ${ }^{2}$, Safeera Khan ${ }^{2}$

1. Medicine, California Institute of Behavioral Neurosciences and Psychology, Fairfield, USA 2. Internal Medicine, California Institute of Behavioral Neurosciences and Psychology, Fairfield, USA 3. Internal Medicine, LaSante Health Center, Brooklyn, USA

Corresponding author: Huseyin Ekin Ergin, ekin-ergin@hotmail.com

\begin{abstract}
The introduction of antiretroviral therapy (ART) has caused some metabolic problems to people who suffer from HIV. ART probably is not the sole reason for these metabolic disorders. Most likely, HIV itself affects the metabolism as well. We conducted research to find the prevalence of the different types of metabolic disorders among $\mathrm{HIV}(+)$ patients. Female gender, high BMI, and older age are among the risk factors for the occurrence of metabolic disorders. Regarding dyslipidemia, hypertriglyceridemia and low high-density lipoproteins (HDLs) are the most common types of dyslipidemia in the studies we included. Protease inhibitors (PIs) are widely known as the most common class of antiretroviral drugs that cause metabolic disorders, and some studies in our review also demonstrated this knowledge. In our review, we concluded that HIV and ART concurrently alter the metabolism, but further research is required about this substantial topic.
\end{abstract}

Categories: Internal Medicine, HIV/AIDS, Infectious Disease

Keywords: antiretroviral, hiv, metabolic syndrome, hypertension, insulin resistance, dyslipidemia

\section{Introduction And Background}

On the report of the Joint United Nations Programme on HIV/AIDS (UNAIDS), there were approximately 37.9 million people who were $\mathrm{HIV}(+)$ at the end of 2018 [1]. Also, nearly 24.7 million people were able to access antiretroviral therapy [1]. The emergence of antiretroviral therapy (ART) in 1996 has increased the life expectancy and life quality of people who have HIV, and the HIV disease is considered a chronic condition [2]. According to the World Health Organization (WHO)'s updated guidelines in 2018, first-line ART for adults usually consists of two nucleoside/nucleotide reverse transcriptase inhibitors (NRTIs) + integrase inhibitors [3]. The second-line ART for adults is usually consisting of two NRTIs + protease inhibitors (PIs) [3].

Received 04/26/2020 Review began 05/02/2020 Review ended 05/11/2020 Published 05/11/2020

\section{() Copyright 2020}

Ergin et al. This is an open access article distributed under the terms of the Creative Commons Attribution License CC-BY 4.0., which permits unrestricted use, distribution, and reproduction in any medium, provided the original author and source are credited.
Adult Treatment Panel III (ATP III) report identified metabolic syndrome (MS) as a group of metabolic abnormalities, which includes: abdominal obesity, increased triglycerides, high blood pressure, increased fasting glucose, and decreased high-density lipoproteins (HDLs) [4]. If three or more criteria are met, MS is present [4]. According to Moore et al., the prevalence of MS among the United States adults has increased by more than $35 \%$ from 1988 - 1994 to $2007-2012$, rising from $25.3 \%$ to $34.2 \%$ [5]. It is also known that MS increases cardiovascular disease (CVD) risk, and it is associated with insulin resistance, prothrombotic state, and proinflammatory state [4].

Recent studies suggested that HIV increases the risk of metabolic disorders even before the introduction of ART [6-11]. Some studies also demonstrated that ART-initiation increases the risk while HIV was not a big risk factor itself [12-18]; another group of studies proposed that HIV and ART increase the risk together [1921]. At the other end of the spectrum, some studies propose combined ART may have good effects on HIV(+) patients who also meet the criteria for MS [22]. Some studies also report that newer antiretroviral drugs decrease the prevalence of insulin resistance among $\mathrm{HIV}(+)$ patients compared to old therapies [23]. PIs are generally well-known for these side effects [15,20,24-26]; also, some NRTIs, especially stavudine, may cause long-term metabolic and cardiovascular complications [24]. Another study did not find PIs as an important contributor to CVD [12]. Some studies compared two NNRTIs for their metabolic effects [27]. A study from Korea has not found a correlation between the use of NNRTI and dyslipidemia [28]. There is also some evidence about the hepatitis C virus (HCV), boosting the risk of these abnormalities caused by HIV/ART [29]. Older age $[6,12,14,15,19,20,30,31]$, high BMI $[6,14,16,28]$ and female gender $[6,9,15,19,20,30]$ are also among the factors, which independently increases the risk of MS in patients with HIV/on ART. Table 1 contains the baseline BMI values of ART-exposed and ART-naive patients in some of the articles. 


\section{Cureus}

\begin{tabular}{|c|c|c|}
\hline Author & Treatment naive & Treatment exposed \\
\hline Osoti et al. (2018) [6] & $23.8 \pm 5.2 \mathrm{~kg} / \mathrm{m}^{2}($ mean $\pm S D)$ & $25.1 \pm 5.9 \mathrm{~kg} / \mathrm{m}^{2}($ mean $\pm S D)$ \\
\hline Muhammad et al. (2017) [14] & $21.6 \pm 5.6 \mathrm{~kg} / \mathrm{m}^{2}($ mean $\pm S D)$ & $21.3 \pm 4.4 \mathrm{~kg} / \mathrm{m}^{2}($ mean $\pm \mathrm{SD})$ \\
\hline Calza et al. (2017) [16] & $23.8 \pm 5.9 \mathrm{~kg} / \mathrm{m}^{2}($ mean $\pm \mathrm{SD})$ & $24.4 \pm 5.6 \mathrm{~kg} / \mathrm{m}^{2}($ mean $\pm \mathrm{SD})$ \\
\hline Oh et al. (2017) [28] & $14.8-33.8 \mathrm{~kg} / \mathrm{m}^{2}$ (range) & $14.5-37.8 \mathrm{~kg} / \mathrm{m}^{2}$ (range) \\
\hline
\end{tabular}

TABLE 1: Mean baseline BMI of the ART-exposed and ART-naive patients

ART can also cause lipodystrophy syndrome [32]. It is defined by changes in adipose tissue and redistribution of fat from the periphery (face, buttocks, legs, arms) to the abdomen, neck, and breasts. Some studies have found that lipodystrophy is more common with dyslipidemia [29,32-34], while some have not found a meaningful relation between dyslipidemia and lipodystrophy [35].

Our study group has reached a consensus about the lack of studies that compare the frequency of HIV/ARTrelated metabolic alterations and its consequence, CVD. Also, there are not enough studies that explain the pathophysiology of metabolic alterations among $\mathrm{HIV}(+)$ patients on ART.

In this review article, we tried to sum up the recent information about the mechanisms, epidemiology, and metabolic effects of different regimens of ART and other factors affecting HIV/ART-related MS and its consequence, CVD.

\section{Review}

\section{Methods}

We conducted a comprehensive literature review via PubMed, PubMedCentral, Google Scholar, and ResearchGate. We used keywords antiretroviral, HIV, MS, hypertension, insulin resistance, dyslipidemia, both alone and in combination to look for the research papers. Our entire database included studies that only focused on the human population. Studies that were other than the English language were excluded. We have included all the full-text articles except one, in our review. Our whole data were collected ethically and legally.

\section{Discussion}

HIV infection is one of the most common diseases in the world; in 2018, there were about 37.9 million people who suffered from this condition, of whom 24.7 million were able to access ART according to UNAIDS [1]. ART has been a great improvement for the survival of these patients [2], but this therapy is also associated with some adverse metabolic effects as well [12-14]. HIV itself may be related to metabolic effects as well [6-8]. Besides, we already know that metabolic disorders can increase the risk of CVD, which is the most common cause of mortality worldwide, according to WHO $[4,36]$.

The way HIV and ART alter the metabolism is not completely clear; these disorders are possibly from the coalescence of inflammation caused by the virus, altered intestinal flora, ART, and traditional risk factors such as old age (Figure 1). Monaco et al. suggested that in patients with untreated HIV infection and low CD4 T-lymphocyte levels, the intestinal microbiome may be altered [37]. Dillon et al. and Brenchley et al. stated that the altered microbiome is associated with systemic inflammation; these findings may be the reason for altered metabolism [38,39]. Peltenburg et al. have found impaired biogenic amine levels in an untreated $\mathrm{HIV}(+)$ patient group [40]. Metabolic dysregulation was also common in this study; biogenic amine disturbances may have a role in the metabolic effects of HIV as well. According to Duro et al., HIV patients with MS had increased levels of C-reactive protein and interleukin-6 [21]. HIV-related metabolic disturbances were more prevalent in female gender in our studies $[6,9,15,19,20,30]$, old age was also an independent risk factor in some of the studies [6,12,14,15,19,20,30,31], and according to some studies, high BMI was a risk factor by itself $[6,12,14,16,28]$. 


\section{Cureus}

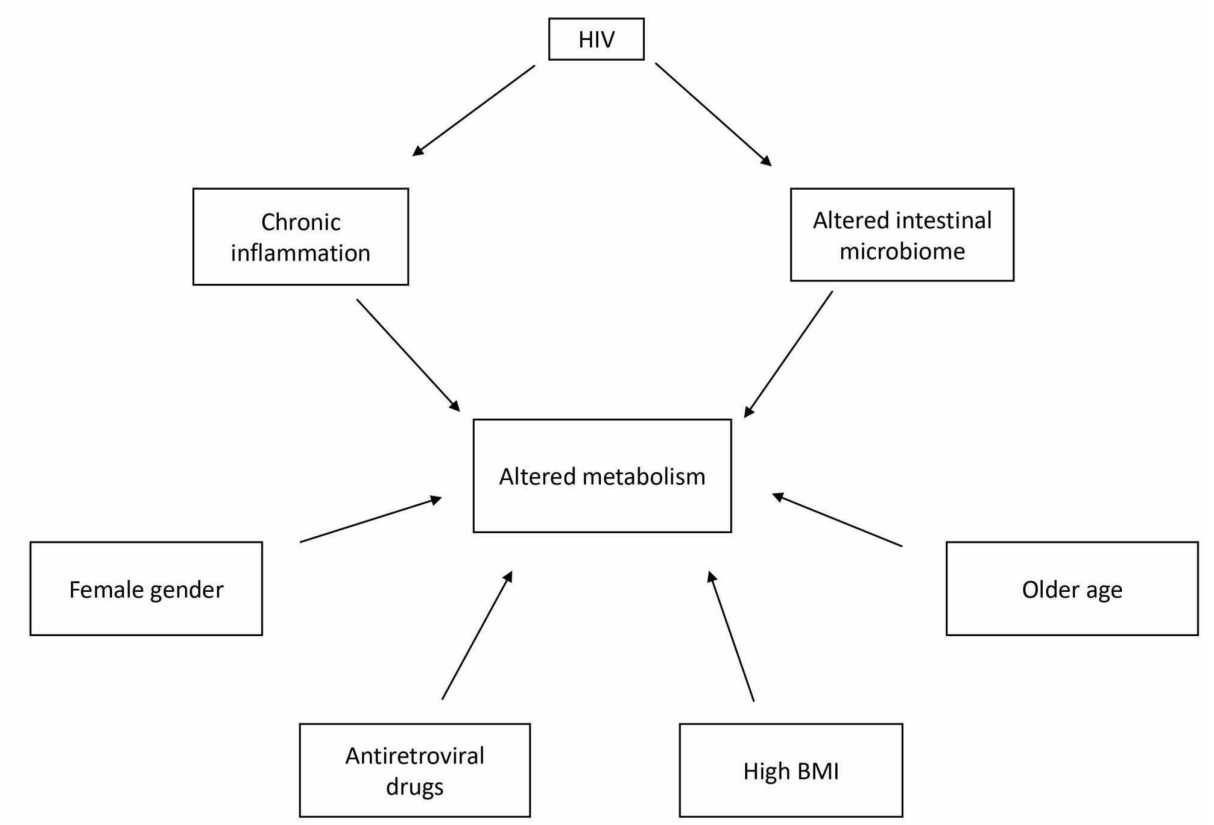

\section{FIGURE 1: Factors associated with metabolic alterations in HIV(+) patients}

The pathogenesis of HIV/ART-related metabolic disturbances is not fully known. As we indicated, there are theories on this subject, such as the chronic inflammation of HIV or alterations in gut flora, but these theories are not proven. Nonsteroidal anti-inflammatory drugs (NSAIDs) can be used to reduce chronic inflammation and may reduce metabolic alterations. Clinical trials using NSAIDs can be conducted to see the effect of chronic inflammation on metabolism better. Antibiotics may affect the gut flora, and clinical trials about the effect of antibiotics and gut flora dysbiosis on the subject can be performed as well.

Dysglycemia

According to WHO, there were about 422 million people who were suffering from diabetes mellitus (DM); there are more people who suffer from impaired plasma glucose when we add the prediabetic population into the equation [41]. Insulin resistance prevents insulin-dependent glucose entry. As per American Diabetes Association's new guidelines in 2020, criteria defining DM are fasting plasma glucose (FPG) level of >126 $\mathrm{mg} / \mathrm{dL}$ after minimum eight hours of fasting, plasma glucose (PG) $>200 \mathrm{mg} / \mathrm{dL}$ two hours after 75 -gram oral glucose tolerance test (OGTT) and hemoglobin A1c (HbA1c) level of $>6.5 \%$; prediabetes criteria are FPG between 100 and $125 \mathrm{mg} / \mathrm{dL}$, PG two hours after OGTT between 140 and $199 \mathrm{mg} / \mathrm{dL}$ and HbA1c level of 5.7\% to $6.4 \%$ [42]. There is quite a bit of possibility that HIV or ART may affect the blood glucose levels and insulin resistance; most of the studies we collected have demonstrated this information. Table 2 contains the studies we collected for dysglycemia.

\begin{tabular}{|c|c|c|c|c|c|}
\hline Author & Drug studied & $\begin{array}{l}\text { Number } \\
\text { of } \\
\text { patients }\end{array}$ & Type of study & Result & Conclusion \\
\hline $\begin{array}{l}\text { Bune et al. (2019) } \\
\text { [31] }\end{array}$ & NRTI + NNRTI + PI & 633 & $\begin{array}{l}\text { Cross- } \\
\text { sectional } \\
\text { study }\end{array}$ & $\begin{array}{l}\text { prevalent in } \% 28 \text { of the ART-naive patients. DM was the } \\
\text { third most frequent component of the MS. }\end{array}$ & $\begin{array}{l}\text { MS was more frequent } \\
\text { in ART-exposed } \\
\text { patients than ART-naive } \\
\text { patients in this study. }\end{array}$ \\
\hline $\begin{array}{l}\text { Padmapriyadarsini } \\
\text { et al. (2018) [7] }\end{array}$ & - & 390 & $\begin{array}{l}\text { Cross- } \\
\text { sectional } \\
\text { study }\end{array}$ & $\begin{array}{l}\text { Increased rate of insulin resistance (17\%) was identified } \\
\text { with ART-naive children. }\end{array}$ & $\begin{array}{l}\text { Prevalence of } \\
\text { cardiometabolic } \\
\text { disorders was higher in } \\
\text { this group, children } \\
\text { should be monitored for } \\
\text { metabolic disorders } \\
\text { after the initiation of } \\
\text { ART. }\end{array}$ \\
\hline
\end{tabular}




\section{Cureus}

\begin{tabular}{|c|c|c|c|c|c|}
\hline $\begin{array}{l}\text { Raposo et al. } \\
\text { (2017) [8] }\end{array}$ & & 87 & $\begin{array}{l}\text { Cross- } \\
\text { sectional } \\
\text { study }\end{array}$ & $\begin{array}{l}\text { The most common metabolic disorders in the patient } \\
\text { group were low HDL cholesterol, hypertriglyceridemia } \\
\text { and abdominal obesity. A major portion of the patients } \\
\text { was in the low-risk group regarding the CVD risk. }\end{array}$ & $\begin{array}{l}\text { Metabolic disorders } \\
\text { were relatively high in } \\
\text { this patient group, } \\
\text { initiation of ART may } \\
\text { increase the prevalence } \\
\text { even higher. }\end{array}$ \\
\hline $\begin{array}{l}\text { Muhammad et al. } \\
\text { (2017) [14] }\end{array}$ & ART & 300 & $\begin{array}{l}\text { Cross- } \\
\text { sectional } \\
\text { study }\end{array}$ & $\begin{array}{l}\text { MS was more prevalent in patients on HAART than } \\
\text { HAART-naive patients. Duration of HAART exposure } \\
\text { wasn't significantly associated with insulin resistance. }\end{array}$ & $\begin{array}{l}\text { HAART, especially } \\
\text { regimens with Pls was } \\
\text { associated with the } \\
\text { increased risk of MS. }\end{array}$ \\
\hline $\begin{array}{l}\text { Kingery et al. } \\
\text { (2016) [13] }\end{array}$ & $\begin{array}{l}\text { The first-line ART regimen was either } \\
\text { tenofivir/emcitrabine or } \\
\text { zidovudine/lamivudine+nevirapine or } \\
\text { efavirenz. Protease inhibitors were used } \\
\text { as second-line ART. }\end{array}$ & 454 & $\begin{array}{l}\text { Cross- } \\
\text { sectional } \\
\text { study }\end{array}$ & $\begin{array}{l}\text { MS was more prevalent in HIV }(+) \text { patients on ART. High } \\
\text { fasting blood glucose was more common in patients on } \\
\text { ART. }\end{array}$ & $\begin{array}{l}\text { MS develops more } \\
\text { frequently in the first 3- } \\
4 \text { years of ART. CVD } \\
\text { risk is also increased } \\
\text { concurrently with MS. }\end{array}$ \\
\hline $\begin{array}{l}\text { Levitt et al. (2016) } \\
\text { [20] }\end{array}$ & $\begin{array}{l}\text { First-line ART (stavudine (d4T), } \\
\text { lamivudine (3TC), and efavirenz or } \\
\text { nevirapine), and second-line ART } \\
\text { (zidovudine (AZT), didanosine (ddl) and } \\
\text { lopinavir- ritonavir (LPV-r)). }\end{array}$ & 1820 & $\begin{array}{l}\text { Cross- } \\
\text { sectional } \\
\text { study }\end{array}$ & $\begin{array}{l}\text { Dysglycemia prevalence was } 37.0 \% \text { of patients on } \\
\text { second-line ART, } 26.0 \% \text { on first-line ART, } 21.6 \% \text { on ART- } \\
\text { naive and } 18.0 \% \text { on community-based survey. High } \\
\text { dysglycemia risk was related to older age and HIV status. } \\
\text { Patients on second-line ART were in the highest risk } \\
\text { category for dysglycemia. }\end{array}$ & $\begin{array}{l}\text { HIV and ART were } \\
\text { found to be a risk factor } \\
\text { for dysglycemia in this } \\
\text { study. Routine } \\
\text { screening should be } \\
\text { done for HIV(+) patients. }\end{array}$ \\
\hline $\begin{array}{l}\text { Maganga et al. } \\
\text { (2015) [18] }\end{array}$ & ART & 454 & $\begin{array}{l}\text { Cross- } \\
\text { sectional } \\
\text { study }\end{array}$ & $\begin{array}{l}\text { Impaired blood glucose was more common in ART- } \\
\text { exposed patients than HIV(-) group. Percentage of } \\
\text { glucose metabolism disorders was similar in ART-naive } \\
\text { and HIV(-) but this finding was not statistically significant. }\end{array}$ & $\begin{array}{l}\text { Risk of glucose } \\
\text { metabolism disorders } \\
\text { was four times higher in } \\
\text { ART-exposed patients } \\
\text { compared to HIV(-) } \\
\text { controls. }\end{array}$ \\
\hline $\begin{array}{l}\text { Mbunkah et al. } \\
\text { (2014) [12] }\end{array}$ & $\begin{array}{l}\text { First-line drug treatment was a } \\
\text { combination of two NRTIs + an NNRTI, } \\
\text { while second-line drug treatment was a } \\
\text { combination of two NRTIs + } 2 \text { Pls. }\end{array}$ & 223 & $\begin{array}{l}\text { Cross- } \\
\text { sectional } \\
\text { study }\end{array}$ & $\begin{array}{l}\text { Hyperglycemia and MS were more common in patients } \\
\text { on ART than ART-naive patients and uninfected } \\
\text { individuals. Prevalence of MS was higher in females than } \\
\text { in males. Patients on first-line drugs had a higher ratio of } \\
\text { MS than patients on second-line therapy. } \\
\text { Lamivudine/stavudine/nevirapine were the highest risk of } \\
\text { drugs for MS. }\end{array}$ & $\begin{array}{l}\text { ART but not HIV } \\
\text { increases the risk of } \\
\text { MS. }\end{array}$ \\
\hline $\begin{array}{l}\text { Araujo et al. (2014) } \\
\text { [23] }\end{array}$ & $\begin{array}{l}\text { Predominance of } \mathrm{Pl} \text { in pretreated } \\
\text { patients ( } 14 \text { vs } 56 \%) \text {, while most first- } \\
\text { line patients received non-nucleoside } \\
\text { analogs ( } 86 \text { vs } 41 \%) \text {. Specifically, DRV } \\
\text { or ATV was primarily used in pretreated } \\
\text { patients }\end{array}$ & 265 & $\begin{array}{l}\text { Cross- } \\
\text { sectional } \\
\text { study }\end{array}$ & $\begin{array}{l}\text { Insulin resistance was found to be less prevalent in } \\
\text { patients on first-line treatment compared to pretreated } \\
\text { patients. }\end{array}$ & $\begin{array}{l}\text { Newer antiretrovirals } \\
\text { were demonstrated to } \\
\text { be safer than older } \\
\text { drugs considering } \\
\text { metabolic disorders. }\end{array}$ \\
\hline $\begin{array}{l}\text { Jain et al. (2007) } \\
\text { [29] }\end{array}$ & ART & 1529 & Observational & $\begin{array}{l}\text { Race, age, high BMI and HCV were risk factors for DM in } \\
\text { HIV(+) patients. Pls were not demonstrated as a risk } \\
\text { factor for DM. }\end{array}$ & $\begin{array}{l}\text { HCV is shown to be a } \\
\text { distinct risk factor for } \\
\text { DM in this patient } \\
\text { group. }\end{array}$ \\
\hline
\end{tabular}

\section{TABLE 2: Selected studies about dysglycemia in the review}

NRTI, nucleotide reverse transcriptase inhibitor; NNRTI, non-nucleoside reverse transcriptase inhibitor; PI, protease inhibitor; ART, antiretroviral therapy; DM, diabetes mellitus; MS, metabolic syndrome; HDL, high-density lipoprotein; HAART, highly active antiretroviral therapy; CVD, cardiovascular disease; $\mathrm{HCV}$, hepatitis $\mathrm{C}$ virus

Several studies suggested that HIV increases the risk of impaired glucose metabolism, even without the use of ART. Padmapriyadarsini et al. conducted a cross-sectional study of ART-naive children in India to assess the associations between HIV and metabolic effects. In their study group, the prevalence of insulin resistance was high, $17 \%$. According to this study, low height-for-age Z-score and weight-for-age Z-score were significantly associated with the development of insulin resistance $(p=0.01$ and $p=0$, respectively) [7].

Raposo et al. conducted a cross-sectional study in Brazil to find any association between HIV and MS in ART-naive adults. They suggest that HIV increases the risk of MS regardless of ART, and impaired plasma 
glucose is significantly associated with the presence of MS $(p<0.05)[8]$.

A cross-sectional study in Cameroon by Mbunkah et al. compared the prevalence of MS among ART-exposed, ART-naive, and HIV(-) control patients. MS was significantly more common in ART-exposed patients, 26.5\% of the patients with MS had hyperglycemia. MS was significantly frequent in the ART-exposed group, especially in patients receiving first-line drugs $(p=0.022)$. The prevalence of MS was highest in patients on lamivudine/stavudine/nevirapine regimen (50\%) [12].

Kingery et al. conducted a study in Tanzania, and they demonstrated that ART was associated with an increased risk of MS. MS was significantly more common in the ART-exposed group (11.3\%) compared to the HIV-negative control group (3.3\%) $(\mathrm{p}=0.04)$. In this study, 11 of the 17 patients with MS had high fasting blood glucose [13].

A study in 2017 by Muhammad et al. compared the rates of MS between ART-naive and ART-exposed patients in Nigeria. The prevalence of MS in patients receiving ART was $19.3 \%$ compared to $5.3 \%$ in ART-naive patients. Insulin resistance identified by homeostatic model assessment for insulin resistance (HOMA-IR) was prevalent in $79.3 \%$ of the ART-exposed patients compared to the $25.0 \%$ ART-naive group $(\mathrm{p}=0.008)$. A particular class of ART or more extended periods of ART-exposure was not significantly associated with insulin resistance [14].

Maganga et al. also concluded that glucose metabolism disorders were significantly more prevalent among ART-exposed patients (32.7\%) compared to ART-naive (8.0\%) and control groups $(7.2 \%)(\mathrm{p}<0.001)$. DM and impaired glucose tolerance were also more common in patients receiving ART $(\mathrm{p}=0.001$ and $\mathrm{p}<001$, respectively). Longer duration of ART or exposure to PIs were not significantly associated with glucose metabolism disorders [18].

A cross-sectional study by Levitt et al. compared the dysglycemia prevalence in a South African patient group [20]. According to their findings, dysglycemia was more common in the patients receiving second-line ART (37.0\%) compared to patients on first-line ART (26.0\%), ART-naive patients (21.6\%) and communitybased survey (18.0\%). The risk of dysglycemia was significantly increased in HIV(+) patients $(p<0.001)[20]$.

Araujo et al. conducted a study in 2017 to compare the prevalence of insulin resistance among different ART regimens and found that insulin resistance is less prevalent in patients using new antiretroviral regimens compared to old therapies. The prevalence of insulin resistance was $21 \%$, significantly higher in patients on PIs (28\%) compared to patients on NNRTIs $(14 \%)(\mathrm{p}<0.01)$ [23].

According to Jain et al., HCV was significantly associated with the development of DM in HIV-infected patients $(\mathrm{p}<0.01)$. In this study, initiation of PIs was not significantly associated with the occurrence of DM [29].

\section{Dyslipidemia}

Three types of lipoproteins are associated with atherosclerotic cardiovascular disease (ASCVD). Low-density lipoprotein (LDL) cholesterol is the most atherogenic form in the blood. Very low-density lipoprotein (VLDL) is another atherogenic lipoprotein, while HDL is not known as an atherogenic type of cholesterol. Atherogenicity of chylomicron is not fully known. According to American Heart Association guidelines, LDL levels of $<100 \mathrm{mg} / \mathrm{dL}$ and total cholesterol levels of $<150$ are ideal. The same guideline also suggests that a $1 \%$ decrease in LDL levels results in a 1\% decrease in ASCVD risk. Table 3 contains the studies we have included about dyslipidemia [43]. 


\section{Cureus}

\begin{tabular}{|c|c|c|c|c|c|}
\hline Author & Drug studied & $\begin{array}{l}\text { Number } \\
\text { of } \\
\text { patients }\end{array}$ & $\begin{array}{l}\text { Type of } \\
\text { study }\end{array}$ & Result & Conclusion \\
\hline $\begin{array}{l}\text { Bune et } \\
\text { al. (2019) } \\
\text { [19] }\end{array}$ & $N R T I+N N R T I+P I$ & 633 & $\begin{array}{l}\text { Cross- } \\
\text { sectional } \\
\text { study }\end{array}$ & $\begin{array}{l}\text { Prevalence of MS was slightly higher in ART-exposed } \\
\text { group compared to ART-naive. Dyslipidemia was } \\
\text { present in } 60.4 \% \text { of the ART-exposed compared to } \\
56.9 \% \text { in ART-naive. }\end{array}$ & $\begin{array}{l}\text { Frequency of } \\
\text { MS was slightly } \\
\text { higher in ART- } \\
\text { exposed } \\
\text { patients. }\end{array}$ \\
\hline $\begin{array}{l}\text { Osoti et } \\
\text { al. (2018) } \\
\text { [6] }\end{array}$ & $\begin{array}{l}\text { Tenofovir/lamivudine } \\
\text { or zidovudine/ } \\
\text { lamivudine }+ \\
\text { nevirapine or } \\
\text { efavirenz. }\end{array}$ & 300 & $\begin{array}{l}\text { Cross- } \\
\text { sectional } \\
\text { study }\end{array}$ & $\begin{array}{l}\text { Low HDL levels were more common in ART-naive } \\
\text { compared to ART-exposed group. }\end{array}$ & $\begin{array}{l}\text { Traditional risk } \\
\text { factors weigh } \\
\text { more than ART } \\
\text { for the } \\
\text { development of } \\
\text { MS in HIV(+) } \\
\text { patients. }\end{array}$ \\
\hline $\begin{array}{l}\text { Calza et } \\
\text { al. (2017) } \\
{[16]}\end{array}$ & ART & 586 & $\begin{array}{l}\text { Cross- } \\
\text { sectional } \\
\text { study }\end{array}$ & $\begin{array}{l}\text { MS was more prevalent in ART-exposed patients than } \\
\text { ART-naive. Most common components for MS were } \\
\text { high triglyceridemia and low HDL. Pl-exposure } \\
\text { increased the risk for MS while integrase inhibitor- } \\
\text { exposure decreased the risk. }\end{array}$ & $\begin{array}{l}\text { Risk for MS } \\
\text { development } \\
\text { was higher in } \\
\text { ART-exposed } \\
\text { group. }\end{array}$ \\
\hline $\begin{array}{l}\text { Anyabolu } \\
\text { et al. } \\
(2017) \\
{[10]}\end{array}$ & - & 393 & $\begin{array}{l}\text { Cross- } \\
\text { sectional } \\
\text { study }\end{array}$ & $\begin{array}{l}\text { Prevalences for high } \mathrm{LDL} \text {, low } \mathrm{HDL} \text {, } \\
\text { hypertriglyceridemia and elevated total cholesterol } \\
\text { were } 17.6 \%, 34.4 \%, 9.9 \%, 11.4 \% \text {, respectively, in ART- } \\
\text { naive patients. }\end{array}$ & $\begin{array}{l}\text { Dyslipidemias } \\
\text { were common } \\
\text { in the patient } \\
\text { group. }\end{array}$ \\
\hline $\begin{array}{l}\text { Fontas et } \\
\text { al. (2004) } \\
\text { [24] }\end{array}$ & $\begin{array}{l}\text { SNRTI } \\
\text { NNRIe }\end{array}$ & 7483 & $\begin{array}{l}\text { Prospective } \\
\text { cohort } \\
\text { study }\end{array}$ & $\begin{array}{l}\text { Triglyceride and LDL levels were lowest in ART-naive } \\
\text { group. Those levels were especially higher in dual-PI } \\
\text { group. NNRTI-exposed group had similar triglyceride } \\
\text { levels to ART-naive. Low HDL was least frequent in } \\
\text { NNRTI-exposed. Risk of low HDL was high in patients } \\
\text { receiving single or dual PI. }\end{array}$ & $\begin{array}{l}\text { NNRTls were } \\
\text { better in this } \\
\text { study } \\
\text { compared to } \\
\text { PIs with respect } \\
\text { to } \\
\text { dyslipidemias. }\end{array}$ \\
\hline
\end{tabular}

\section{TABLE 3: Description of selected studies about dyslipidemia from the review}

NRTI, nucleotide reverse transcriptase inhibitor; NNRTI, non-nucleoside reverse transcriptase inhibitor; PI, protease inhibitor; ART, antiretroviral therapy; DM, diabetes mellitus; MS, metabolic syndrome; HDL, high-density lipoprotein

In some studies, ART-naive individuals were at risk of having dyslipidemia before the ART-initiation. Osoti et al. found that traditional factors were a more significant predictor for MS than ART in a study group with 164 ART-exposed and 136 ART-naive individuals. According to this study, MS was slightly more prevalent in patients receiving ART (16.9\%) than ART-naive (15.2\%), but this finding was not statistically significant ( $\mathrm{p}$ > 0.05). Almost all patients were receiving NRTI (99\%), while $92 \%$ and $6.7 \%$ were on NNRTI and PI, respectively. $56 \%$ of the patients were receiving nevirapine-based triple therapy (tenofovir/lamivudine/nevirapine) while efavirenz-based triple therapy (tenofovir/lamivudine/efavirenz) was the second most common regimen with a prevalence of $36 \%$. Prevalence of high triglyceride levels was similar in both ART-exposed and ART-naive patients, but low HDL levels were significantly more common in ART-naive patients $(\mathrm{p}=0.003)[6]$.

Anyabolu et al. concluded a cross-sectional study in South-East Nigeria with 393 patients to demonstrate the HIV effect on dyslipidemia in 2017. In their study, the prevalence of different types of dyslipidemias was 17.6\% for high serum LDL, $11.4 \%$ for elevated total cholesterol, 9.9\% for high serum triglycerides, and $34.4 \%$ for low serum HDL. Dyslipidemia and CD4 lymphocyte count were significantly associated $(p=0.027)$ [10].

Calza et al. also suggested that MS risk increased in ART-exposed patients. In this cross-sectional study, MS was significantly higher in the ART-exposed group; high triglycerides and low HDL were the most common features of MS and levels of total cholesterol, triglycerides, and LDL was significantly higher while HDL levels were significantly lower in patients receiving ART. NNRTIs rilpivirine and efavirenz were not significantly associated with the development of MS while dual-PI therapies darunavir/ritonavir (OR: 1.89, $\mathrm{p}$ $=0.014)$ and atazanavir/ritonavir $(\mathrm{OR}: 1.61, \mathrm{p}=0.039)$ had a significant positive association with MS. The decreased risk of having MS in integrase inhibitor receiving patients was not statistically significant [16]. 
Bune et al. conducted a cross-sectional study in Southern Ethiopia involving 422 ART-exposed and 211 ARTnaive patients to compare the prevalence of MS in ART-exposed and ART-naive patients. MS was prevalent in $22.0 \%$ in the patients receiving ART while $20.9 \%$ in the ART-naive patients; the most common component of MS was dyslipidemia. Dyslipidemia was seen in $59.2 \%$ of the patients, and the prevalence was $60.4 \%$ and 56.9\% in ART-exposed and ART-naive, respectively; high triglyceride levels (37\%) and low HDL levels (34.3\%) were the most frequent types of dyslipidemia [19].

Fontas et al. conducted a prospective cohort study with 7483 patients in 2004 . In the study, triglyceride, total cholesterol, and LDL levels were lowest in the ART-naive group and highest in patients receiving two different PIs. Patients receiving NNRTIs had close triglyceride levels to ART-naive patients. There was no significant difference among groups for HDL levels, but it was highest in the group receiving NNRTI. In terms of risk of dyslipidemia, PI-exposed patients had a significantly higher risk of high triglycerides and total cholesterol/HDL levels. High total cholesterol risk was significantly higher in the double-PI group compared to the ART-naive group. Each ART-exposed groups were compared to each other about the risk of dyslipidemia as well; patients on double-PI therapy were at a significantly higher risk of dyslipidemias barring LDL and HDL levels. On the other hand, the risk of abnormalities in LDL, HDL, triglycerides, and total cholesterol/HDL levels were significantly lower in the NNRTI-exposed group compared to other drugexposed groups. Within PIs, ritonavir (RTV)-exposed patients had a significantly higher risk of high total cholesterol levels than nelfinavir (NLF), and high total cholesterol/HDL levels than indinavir (IDV); patients receiving saquinavir (SQV) had the lowest risk of high total cholesterol/HDL. Concerning NNRTIs, patients on efavirenz (EFV) had a significantly higher risk of high triglyceride levels than patients on nevirapine (NVP) while both groups were at a similar degree of risk to have high total cholesterol levels [24].

Hypertension

According to WHO, hypertension is one of the most common disorders in the world; 1.13 billion people in the world have hypertension, even more, when prehypertensive patients are added to the equation [44]. Per American Heart Association and American College of Cardiology's latest guideline of high blood pressure, categories of blood pressure are: normal levels [systolic blood pressure (SBP): $\leqslant 120 \mathrm{mmHg}$ and diastolic blood pressure (DBP): $\leqslant 80 \mathrm{mmHg}$, elevated (SBP: $120-129 \mathrm{mmHg}, \mathrm{DBP}:<80 \mathrm{mmHg}$ ), stage 1 hypertension (SBP between 130 and $139 \mathrm{mmHg}$, DBP between 80 and $89 \mathrm{mmHg}$ ), and stage 2 hypertension (SBP $\geqslant 140$ $\mathrm{mmHg}$ and DBP $\geqslant 90 \mathrm{mmHg}$ ) [45]. High blood pressure may be a result of HIV or ART, according to some studies we collected.

Muhammad et al. conducted a cross-sectional study in northwestern Nigeria to assess the prevalence of MS among 150 ART-naive and 150 ART-exposed patients [14]. In the ART-exposed group, 135 of the patients were receiving first-line therapy, and 15 patients were receiving second-line therapy [12]; the prevalence of MS in the ART-exposed group was 29 (19.3\%), while it was 8 (5.3\%) in the ART-naive group [14]. High blood pressure was the most common feature of MS in both ART-exposed and ART-naive patients, $82.8 \%$ and $87.5 \%$, respectively, but these findings were not statistically significant $(p=0.61)$ [14]. High blood pressure was considerably associated with the occurrence of MS $(p<0.001)[14]$.

The effect of ART was evaluated in a cross-sectional study by Dimala et al. in Cameroon, 100 first-line ARTexposed patients, and 100 ART-naive patients were involved in this study. Hypertension was significantly more prevalent in the ART-exposed patients than the ART-naive group; 38\% and 19\%, respectively $(\mathrm{p}=$ 0.003). Average SBP and DBP values were also higher in ART-exposed patients, $131 \pm 31 \mathrm{mmHg}$ and $80 \pm 13$ $\mathrm{mmHg}$ and $125 \pm 19 \mathrm{mmHg}$ and $77 \pm 12 \mathrm{mmHg}$, respectively, but these findings were not statistically significant $(\mathrm{p}=0.06$ and $\mathrm{p}=0.118)[17]$.

In a cross-sectional study that included 422 ART-exposed and 211 ART-naive patients by Bune et al., the prevalence of MS in ART-exposed was 22.5\% while it was 20.9\% in ART-naive. The prevalence of hypertension in ART-naive was 57.3\% compared to 56.9\% in ART-exposed patients, and hypertension was present in about $92 \%$ of the patients with MS. Hypertension was the only feature of MS that was more prevalent in ART-naive than ART-exposed [19].

\section{Limitations}

We could not find enough information about the impact of different drug classes on hypertension, some studies compare the effect of classes on dyslipidemia and insulin resistance, but similar studies are not available for hypertension. Another limitation of our review is most studies we included are cross-sectional studies; thus, there is not much information about the causality.

\section{Conclusions}

The effect of HIV or ART on MS is not entirely understood yet. Multiple factors probably play a role in the occurrence of those metabolic alterations. In our review, we came to the following conclusions: both HIV and ART may have a role in the development of metabolic disorders; these adverse effects are more common in women, people in high BMI, and older people. Also that PIs are the most dangerous class of drugs concerning metabolic disorders. There are not many studies that explain the pathophysiology of HIV/ART- 
related metabolic alterations; further information about their mechanism is mandatory to prevent or treat these conditions. A detailed comparison of frequencies of ART-related metabolic alterations among different races is also another valuable information we do not have. Further research about genes or proteins in various races that affect the rate or severity of MS in patients on ART can be conducted after this review. A study that enlightens the reasons for the higher prevalence of metabolic alterations in women can be undertaken as well.

\section{Additional Information \\ Disclosures}

Conflicts of interest: In compliance with the ICMJE uniform disclosure form, all authors declare the following: Payment/services info: All authors have declared that no financial support was received from any organization for the submitted work. Financial relationships: All authors have declared that they have no financial relationships at present or within the previous three years with any organizations that might have an interest in the submitted work. Other relationships: All authors have declared that there are no other relationships or activities that could appear to have influenced the submitted work.

\section{References}

1. Global HIV \& AIDS statistics - 2019 fact sheet . (2019). Accessed: April 17, 2020: https://www.unaids.org/en/resources/fact-sheet.

2. Collaboration of Observational HIV Epidemiological Research Europe (COHERE) in EuroCoord, Lewden C, Bouteloup V, et al.: All-cause mortality in treated HIV-infected adults with CD4 $\$ 500 / \mathrm{mm} 3$ compared with the general population: evidence from a large European observational cohort collaboration. Int J Epidemiol. 2012, 41:433-445. 10.1093/ije/dyr164

3. World Health Organization: Updated recommendations on first-line and second-line antiretroviral regimens and post-exposure prophylaxis and recommendations on early infant diagnosis of HIV: interim guidelines: supplement to the 2016 consolidated guidelines on the use of antiretroviral drugs for treating and preventing HIV infection. Grubb I, Breuer D (ed): World Health Organization, Geneva; 2018.

4. Third Report of the National Cholesterol Education Program (NCEP) expert panel on detection, evaluation, and treatment of high blood cholesterol in adults (Adult Treatment Panel III) final report. Circulation. 2002, 106:3143-3421. 10.1161/circ.106.25.3143

5. Moore JX, Chaudhary N, Akinyemiju T: Metabolic syndrome prevalence by race/ethnicity and sex in the United States, National Health and Nutrition Examination Survey, 1988-2012. Prev Chronic Dis. 2017, 14:e24. 10.5888/pcd14.160287

6. Osoti A, Temu TM, Kirui N, et al.: Metabolic syndrome among antiretroviral therapy-naive versus experienced HIV-infected patients without preexisting cardiometabolic disorders in Western Kenya. AIDS Patient Care. 2018, 32:215-222. 10.1089/apc.2018.0052

7. Padmapriyadarsini C, Shet A, Srinivasan R, et al.: High prevalence of lipid abnormalities and insulin resistance among antiretroviral naïve HIV-infected children in India. Pediatr Infect Dis J. 2018, 37:253-257. 10.1097/INF.0000000000001829

8. Raposo MA, Armiliato GNA, Guimarães NS, et al.: Metabolic disorders and cardiovascular risk in people living with HIV/AIDS without the use of antiretroviral therapy. Rev Soc Bra Med Tro. 2017, 50:598-606. 10.1590/0037-8682-0258-2017

9. Nguyen KA, Peer N, de Villiers A, et al.: Metabolic syndrome in people living with human immunodeficiency virus: an assessment of the prevalence and the agreement between diagnostic criteria. Int J Endocrinol. 2017, 2017:1613657. 10.1155/2017/1613657

10. Anyabolu EN: Dyslipidemia in people living with HIV-AIDS in a tertiary hospital in South-East Nigeria . Pan Afr Med J. 2017, 28:204. 10.11604/pamj.2017.28.204.13505

11. Rogalska-Płońska M, Grzeszczuk A, Rogalski P, Łucejko M, Flisiak R: Metabolic syndrome in HIV infected adults in Poland. Kardiol Pol. 2018, 76:548-553. 10.5603/KP.a2017.0249

12. Mbunkah HA, Meriki HD, Kukwah AT, Nfor O, Nkuo-Akenji T: Prevalence of metabolic syndrome in human immunodeficiency virus-infected patients from the South-West region of Cameroon, using the adult treatment panel III criteria. Diabetol Metab Syndr. 2014, 6:92. 10.1186/1758-5996-6-92

13. Kingery JR, Alfred Y, Smart LR, et al.: Short-term and long-term cardiovascular risk, metabolic syndrome and HIV in Tanzania. Heart. 2016, 102:1200-1205. 10.1136/heartjnl-2015-309026

14. Muhammad FY, Gezawa ID, Uloko A, Yakasai AM, Habib AG, Iliyasu G: Metabolic syndrome among HIV infected patients: a comparative cross sectional study in northwestern Nigeria. Diabetes Metab Syndr. 2017, 11(Suppl 1):523-529. 10.1016/j.dsx.2017.03.046

15. Guira O, Tiéno H, Diendéré AE, et al.: Features of metabolic syndrome and its associated factors during highly active antiretroviral therapy in Ouagadougou (Burkina Faso). J Int Assoc Provid AIDS Care. 2016, 15:159-163. 10.1177/2325957415601503

16. Calza L, Colangeli V, Magistrelli E, et al.: Prevalence of metabolic syndrome in HIV-infected patients naive to antiretroviral therapy or receiving a first-line treatment. HIV Clin Trials. 2017, 18:110-117. 10.1080/15284336.2017.1311502

17. Dimala CA, Atashili J, Mbuagbaw JC, Wilfred A, Monekosso GL: Prevalence of hypertension in HIV/AIDS Patients on Highly Active Antiretroviral Therapy (HAART) compared with HAART-naïve patients at the Limbe Regional Hospital, Cameroon. PLoS One. 2016, 11:e0148100. 10.1371/journal.pone.0148100

18. Maganga E, Smart LR, Kalluvya S, et al.: Glucose metabolism disorders, HIV and antiretroviral therapy among Tanzanian adults. PLoS One. 2015, 10:e0134410. 10.1371/journal.pone.0134410

19. Bune GT, Yalew AW, Kumie A: The global magnitude of metabolic syndrome among antiretroviral therapy (ART) exposed and ART-naïve adult HIV-infected patients in gedio-zone, southern Ethiopia: comparative 
cross-sectional study, using the Adult Treatment Panel III criteria. Diabetes Metab Syndr. 2019, 13:28332841. 10.1016/j.dsx.2019.07.051

20. Levitt NS, Peer N, Steyn K, et al.: Increased risk of dysglycaemia in South Africans with HIV; especially those on protease inhibitors. Diabetes Res Clin Pract. 2016, 119:41-47. 10.1016/j.diabres.2016.03.012

21. Duro M, Manso MC, Barreira S, Rebelo I, Medeiros R, Almeida C: Metabolic syndrome in human immunodeficiency virus-infected patients. Int J STD AIDS. 2018, 29:1089-1097. 10.1177/0956462418775188

22. Krishnan S, Schouten JT, Atkinson B, et al.: Changes in metabolic syndrome status after initiation of antiretroviral therapy. J Acquir Immune Defic Syndr. 2015, 68:73-80. 10.1097/QAI.0000000000000397

23. Araujo S, Bañón S, Machuca I, Moreno A, Pérez-Elías MJ, Casado JL: Prevalence of insulin resistance and risk of diabetes mellitus in HIV-infected patients receiving current antiretroviral drugs. Eur J Endocrinol. 2014, 171:545-554. 10.1530/EJE-14-0337

24. Fontas E, van Leth F, Sabin CA, et al.: Lipid profiles in HIV-infected patients receiving combination antiretroviral therapy: are different antiretroviral drugs associated with different lipid profiles?. J Infect Dis. 2004, 189:1056-1074. 10.1086/381783

25. Santiprabhob J, Tanchaweng S, Maturapat S, et al.: Metabolic disorders in HIV-infected adolescents receiving protease inhibitors. Biomed Res Int. 2017, 2017:7481597. 10.1155/2017/7481597

26. Patel K, Lindsey J, Angelidou K, Aldrovandi G, Palumbo P, IMPAACT P1060 Study Team: Metabolic effects of initiating lopinavir/ritonavir-based regimens among young children. AIDS. 2018, 32:2327-2336. 10.1097/QAD.0000000000001980

27. Domingos H, Cunha RV, Paniago AM, Martins DM, Elkhoury EB, Souza AS: Metabolic effects associated to the highly active antiretroviral therapy (HAART) in AIDS patients. Braz J Infect Dis. 2009, 13:130-136. 10.1590/s1413-86702009000200012

28. Oh DH, Ahn JY, Kim SI, et al.: Metabolic complications among Korean patients with HIV infection: The Korea HIV/AIDS Cohort Study. J Korean Med Sci. 2017, 32:1268-1274. 10.3346/jkms.2017.32.8.1268

29. Jain MK, Aragaki C, Fischbach L, et al.: Hepatitis C is associated with type 2 diabetes mellitus in HIVinfected persons without traditional risk factors. HIV Med. 2007, 8:491-497. 10.1111/j.14681293.2007.00499.x

30. Sears S, Buendia JR, Odem S, et al.: Metabolic syndrome among people living with HIV receiving medical care in Southern United States: prevalence and risk factors. AIDS Behav. 2019, 23:2916-2925. 10.1007/s10461-019-02487-8

31. Mohammed AE, Shenkute TY, Gebisa WC: Diabetes mellitus and risk factors in human immunodeficiency virus-infected individuals at Jimma University Specialized Hospital, Southwest Ethiopia Diabetes . Metab Syndr Obes. 2015, 8:197-206. 10.2147/DMSO.S80084

32. Sculier D, Toutous-Trellu L, Verolet C, Matthes N, Lecompte T, Calmy A: Lipohypertrophy and metabolic disorders in HIV patients on antiretroviral therapy: a systematic multidisciplinary clinical approach. J Int AIDS Soc. 2014, 17:19559. 10.7448/IAS.17.4.19559

33. Indumati V, Vijay V, Shekhanawar MS, et al.: Comparison of serum lipid profile in HIV positive patients on ART with ART naïve patients. J Clin Diagn Res. 2014, 8:CC06-CC09. 10.7860/JCDR/2014/9685.4979

34. Innes S, Abdullah KL, Haubrich R, Cotton MF, Browne SH: High prevalence of dyslipidemia and insulin resistance in HIV-infected prepubertal African children on antiretroviral therapy. Pediatr Infect Dis J. 2016, 35:e1-e7. 10.1097/INF.0000000000000927

35. Iwuala SO, Lesi OA, Olamoyegun MA, Sabir AA, Fasanmade OA: Lipoatrophy among patients on antiretroviral therapy in Lagos, Nigeria: prevalence, pattern and association with cardiovascular risk factors. Niger J Clin Pract. 2015, 18:626-632. 10.4103/1119-3077.154208

36. Cardiovascular diseases (CVDs). (2017). Accessed: April 19, 2020: https://www.who.int/en/news-room/factsheets/detail/cardiovascular-diseases-(cvds).

37. Monaco CL, Gootenberg DB, Zhao G, et al.: Altered virome and bacterial microbiome in human immunodeficiency virus-associated acquired immunodeficiency syndrome. Cell Host Microbe. 2016, 19:311322. 10.1016/j.chom.2016.02.011

38. Dillon SM, Lee EJ, Kotter CV, et al.: An altered intestinal mucosal microbiome in HIV-1 infection is associated with mucosal and systemic immune activation and endotoxemia. Mucosal Immunol. 2014, 7:983994. 10.1038/mi.2013.116

39. Brenchley JM, Price DA, Schacker TW, et al.: Microbial translocation is a cause of systemic immune activation in chronic HIV infection. Nat Med. 2006, 12:1365-1371. 10.1038/nm1511

40. Peltenburg NC, Schoeman JC, Hou J, et al.: Persistent metabolic changes in HIV-infected patients during the first year of combination antiretroviral therapy. Sci Rep. 2018, 8:16947. 10.1038/s41598-018-35271-0

41. World Health Organization: Global report on diabetes. Varghese C, Riley L, Harvey A (ed): World Health Organization, Geneva; 2016.

42. American Diabetes Association: Classification and diagnosis of diabetes: Standards of Medical Care in Diabetes-2020. Diabetes Care. 2020, 43:S14-S31. 10.2337/dc20-S002

43. Grundy SM, Stone NJ, Bailey AL, et al.: 2018 AHA/ACC/AACVPR/AAPA/ABC/ACPM/ADA/AGS/APhA/ASPC/NLA/PCNA guideline on the management of blood cholesterol: executive summary. J Am Coll Cardiol. 2019, 73:3168-3209. 10.1016/j.jacc.2018.11.002

44. Hypertension. (2019). Accessed: April 18, 2020: https://www.who.int/news-room/factsheets/detail/hypertension.

45. Whelton PK, Carey RM, Aronow WS, et al.: 2017 ACC/AHA/AAPA/ABC/ACPM/AGS/APhA/ASH/ASPC/NMA/PCNA guideline for the prevention, detection, evaluation, and management of high blood pressure in adults: a report of the American College of Cardiology/American Heart Association Task Force on Clinical Practice Guidelines. Hypertension. 2018, 71:e13-e115. 10.1161/HYP.0000000000000065 